\title{
Discourse Analysis of Science Teachers Talk as a Self-reflective Tool for Promoting Effective NOS Teaching
}

\author{
Panagiotis Piliouras ${ }^{1}$, Katerina Plakitsi ${ }^{2, *} \&$ Georgios Nasis ${ }^{3}$ \\ ${ }^{1}$ Greek Ministry of Education, Greece \\ ${ }^{2}$ Department of Early Childhood Education, School of Education, University of Ioannina, Greece \\ ${ }^{3}$ Greek Church, Greece \\ *Correspondence: Department of Early Childhood Education, School of Education, University of Ioannina, Greece. \\ E-mail: kplakits@cc.uoi.gr
}

Received: September 18, 2015

Accepted: October 6, 2015 Online Published: December 17, 2015

doi:10.5430/wje.v5n6p96

URL: http://dx.doi.org/10.5430/wje.v5n6p96

\begin{abstract}
Teaching the Nature of Science (NOS) in elementary schools and in higher education institutions has become the focus of the science education research community because there is a need to redefine teaching methods and practices. Studies have shown that elementary teachers' views and attitudes towards teaching the NOS are not always compatible with the current acceptable theoretical framework identified by the research community. Researchers and scholars have proposed a variety of approaches in pre-service and in-service teacher training so that teachers change their beliefs, views and attitudes towards teaching the NOS. Amongst these there are two major trends, the implicit and explicit training approaches. Literature review has shown that the later is relatively more effective. Our proposal concerns the use of an explicit strategy to enable teachers analyse their own discourses in cooperation with researchers and reflect on their own views on aspects concerning teaching the NOS. The proposal is based on the assumption that the critical reflection on the ways people construct meanings may enable the exploration of alternative ways to communicate actions during science lessons. An empirical example of this discourse analysis oriented in explicit approach is presented and a proposal of possible series of discourse analysis oriented in actions for promoting more effective NOS teaching is discussed.
\end{abstract}

Keywords: Teachers'professional development; NOS teaching; Discourse analysis

\section{NOS and Scientific Literacy}

The term "scientific literacy" has been used as a general framework for discussion on science education since early 1980's ( AAAS, 1993; NRC, 1996). One of the characteristics that have emerged as agreed aspects on the meaning of the concept of scientific literacy is the need for students to gain an understanding of NOS (Matthews, 1998). Lederman (2007) argues that NOS understanding has been the aim of science education at least from the first decade of the 20th century. Reform efforts around the world stress the importance of developing images of science that are consistent with current scientific practices (AAAS, 1993; Driver et al, 1996; NRC, 1996; Hodson, 1998; Millar \& Osborne, 1998; Aikenhead, 2000; NRC, 2012).

Nowadays a vast majority of scientists, science educators, and science education organizations have agreed upon the objective of helping students develop informed conceptions on NOS (Matthews, 1998; McComas, 2005; Lederman, 2007, NRC, 2012). Osborne et al (2003) state:

"Contemporary society, it is argued ... that requires a populace who has a better understanding of the workings of science thus enabling them to engage in a critical dialogue about the political and moral dilemmas posed by science and technology and arrives at considered decisions."

Science curriculum reforms have taken place in many countries and in Greece to give scientific literacy a central place by developing pupils' ideas about NOS (AAAS, 1993; NRC, 1996; NRC, 2012). According to Driver et al (1996, p.127), five main arguments, which are related with utilitarian, democratic, cultural, moral and science 
learning issues, to substantiate why understanding the NOS is a fundamental characteristic of a scientific literate citizen.

Matthews et al (2005) argue that "science literacy should be interpreted in a broad generous sense, so that literacy is seen as involving an understanding and appreciation the NOS, including its history, methodology and interrelations with culture. The assumption adopted in this paper is that science teachers play a crucial role in implementing science learning activities oriented to this approach. Also, we assert that, during science lessons, teachers intentionally or unintentionally communicate views on many important science learning aspects such as NOS but also on the nature of learning and teaching and nature of science language.

This proposal concerns an explicit training strategy concerning the promotion of suitable views on NOS aspects by the science teachers. This strategy involves the analysis of teachers' own discourses in cooperation with researchers, as a reflective tool for the detection of views concerning the image of science. Next, a brief literature review on NOS in relation with science teacher education is presented along with a theoretical framework on the use of discourse analysis as research and training tool. After reporting an empirical example to this direction, a proposal of a possible sequence of discourse analysis of science teacher actions is discussed.

\section{Tracing Contemporary Assumptions about NOS}

Literature review reveals that the phrase "Nature of Science" (NOS) is related with the terms "Nature of Sciences" and "ideas-about-science" (McComas et al, 1998). Philosophers, historians, scientists, science educators and researchers agree that there is no common view accepted about the image of scientific research and development of scientific knowledge (Duschl, 1994; Osborne et al, 2003; Lederman, 2007).

Lederman (1998) argues that there have been many disputes among philosophers, historians and science educators on NOS, which are not related to teaching the science subject at school. Furthermore, he argues that this occurs because there is a level of generality on issues concerning NOS which is accepted by all, although there are also some minor disputes. It is significant that in recent years several researchers like McComas et al (1998), Lederman et al (2002), Osborne et al (2003), and McComas (2005) have formulated a series of views on NOS - which although are not always converging - they are appropriate to deal with during science lessons.

It is argued that a contemporary accepted view about this issue is that: “...science is dynamic, changing and tentative. It is not a static collection of facts. We cannot take current scientific knowledge to be complete and final" (Bell et al, 2000, p.564). Lederman \& Lederman (2004) refer to seven aspects of NOS that can be related to students' lives, which may form an understanding of scientific knowledge as tentative, subjective, empirically based, socially embedded and depending on human imagination and creativity. Two additional aspects involve the distinction between observation and inference and the distinction between theories and laws. According to McComas (2005), some of the core NOS ideas appropriate to inform curriculum development, instruction and teacher training are the following: a) science demands and relies on empirical evidence, scientific knowledge is tentative, durable and self correcting; b) science has a subjective element; c) there are historical, cultural and social influences on the practice and direction of science; d) science and technology impact each other, but they are not the same; e) science and its methods cannot answer all questions.

It is evident, therefore, that there are many agreed aspects of NOS that could be taken into account in pre-service teacher training on discourse analysis oriented actions. For example, analyzing science pre-service teachers talk or a whole class discussion one can ascertain whether a teacher makes references on historical, cultural and social dimensions of scientific practices; whether he/she presents an one and absolute scientific method, whether he/she presents the scientific knowledge as tentative or not and so on. Additionally, the context and numbers of teachers involved in the discourse analysis plays significant role. For example, it should be taken into consideration whether the teacher has undertaken the role of teacher-researcher and reflects on her own verbal or written account or he/she examines and analyses other science teachers' talk.

\section{NOS and Science Teacher Education}

Teaching the NOS in elementary schools and in higher education institutions has become the focus of the science education research community because there is a need to redefine teaching methods and practices (Hodson, 1988; Driver et al, 1996; Jenkins, 1996; Matthews, 1998; McComas et al, 1998; Abd-El-Khalick \& Lederman, 2000; Adúriz-Bravo, 2003; Clough, 2006; Seroglou \& Adúriz-Bravo, 2007; Akerson et al, 2009). 
Two assumptions appear to dominate policy and research related to teacher conceptions of NOS. Lederman (1992) argues that teacher conceptions are directly related to student conceptions, and teacher conceptions necessarily influence classroom practice. Despite what happens between those two assumptions, it seems that teachers' views on NOS have a significant impact on the students' learning. Clough and Olson (2004) support that:

“...mistaken ideas of science likely affect students' attitudes toward science and learning in science classes (p.28) ... Because NOS images are inextricably connected to science content and how it is presented to students, all science teachers and courses communicate a story to students about what science is, how science works, and other important issues about NOS. Teachers do not purposely teach mistaken ideas about NOS, but because they cannot escape teaching it, purposeful attention to the strategies suggested here is important (p.30)".

Studies have confirmed that students do not develop desired understandings about NOS from typical classroom instruction (Lederman, 1992; Ryan \& Aikenhead, 1992; Abd-El-Khalick et al, 1998; Lederman et al, 1999; Lederman, 1999; Akerson \& Abd-El-Khalick, 2005). A frequently mentioned objective of science education in the last two decades has been for teachers to possess a valid understanding about NOS, which they in turn, will transmit to learners (Akerson et al, 2010).

Various approaches have been tried out in order to change or transform conceptions of teachers about NOS. These include the conceptual change approach (Akerson, \& Abd-El-Khalick, 2000; Johnston, 2001; Abd-El-Khalick \& Akerson, 2004), and the explicit, reflective-based approach (Akerson et al, 2000; Bell et al, 2000; Schwartz et al, 2004, Akerson \& Volrich 2006). According to Abd-El-Khalick and Lederman (2000), these training attempts could be categorized into two general approaches: implicit and explicit.

- Implicit attempts utilized science process-skills instruction or engagement in science-based inquiry activities

- Explicit attempts used instruction geared towards various aspects of NOS and/or instruction that employed elements from history and philosophy of science.

Review of research reports indicated that the explicit approach was relatively more effective in enhancing teachers' views on instruction because it encourages learners to be aware of and reflect upon their own conceptions (Abd-El-Khalick \& Lederman, 2000; Akerson \& Volrich, 2006).

In conclusion, educational science research reveal that teachers and students need to further develop their understanding of NOS and indicate the critical role teachers play in developing this understanding. Also, research literature points out the effectiveness of explicit instruction in teacher education and the exploitation of authentic historical science events to present the social and cultural restrictions of scientific endeavor. In this line, we propose discourse analysis as training and reflective tool in a meta-didactical level that could be combined with explicit instruction on aspects of NOS and the exploitation of authentic historical science events.

\section{Discourse Analysis as a Research and Training Tool}

In the past two decades, the study of discourse, oriented on sociocultural theories, has become an important aspect for those concerned with the investigation of learning in social settings (Lemke, 1995; Wertsch \& Toma, 1995; Hicks, 1996; Gee, 1999). By studying discursive activity within science classrooms, researchers have provided new insights into the complex and dynamic relationships between language, social practices, and learning (Wells, 1999; Mortimer $\&$ Scott, 2003).

These approaches examine teachers' and students' talk in order to determine whether they "put obstacles" or "facilitate" the learning process and help creating the desirable teaching/learning conditions in relation to the adopted scientific literacy definitions. According to Luke (1995), discourse analysis examines how social relations, identity, knowledge and power are constructed on written and oral texts within communities. Wertsch (1991) regards conscious reflection - like discourse analysis utilised by teachers themselves- as an important element of development within mediated action (Roth, Goulart, Plakitsi, 2013a, 2013b). He also mentions that: “....mediating tools, such as language is often used with little or no sense. In fact, this occurs when someone is confronted with a similar example, which could be aware of alternative ways of behaviour" (p.126). Similarly Burbules and Bruce (2001) argue that the more someone develops this analysis of speech, the more likely he is to understand the possibilities of adopting desirable learning practices in classrooms.

Discourse analysis theorists argue that discourses can never be "neutral" or value free. Discourses always reflect ideologies, systems of values, beliefs and social practices (Gee \& Green, 1998). This implies that science teacher talk 
during lessons communicate intentionally or unintentionally, concrete aspects about NOS (Oliveira et al, 2012; Ryder \& Leach, 2008). As mentioned above research studies revealed that the majority of science teachers do not possess informed concepts about NOS. It can be assumed, therefore that science teachers it is possible unintendedly to communicate a deficient image of science.

The following teacher - discussion is an example that illustrates abovementioned assumption. The discussion took place in a 5th grade elementary class in a public school in Athens, Greece, during a science lesson concerning the topic of evaporation in the spring of 2012.

\section{Extract 1}

1 (Teacher): We are going to interpret the phenomenon of evaporation. Whatever we observe in sciences we call it phenomenon. Since ancient years people used to observe phenomena trying to explain them. What explanation did they give for the lightning?

2 (Student 1): They said fables.

3 (Teacher): What did they say about the lightning?

4 (Student 2): That Zeus throws them.

5 (T): Right. Later, of course, in Ephesus, Militos etc some people started to say that phenomena could not be explained by fables and tried to give certain reasonable explanations. This is what you do at the moment. You see something and you try to interpret it. Let see the interpretations you wrote.

6 (Student 3): That the water is evaporated.

It is apparent that the teacher deliberately tried to create particular meanings on issues concerning the observation and the interpretation of the phenomena (communication actions 1 and 5). Yet, he did not narrow down his guidance to the issues concerned the evaporation experiments but enhanced the instruction with important communicative actions regarding history and philosophy of science and NOS aspects. The particular teacher is considered to be an expert in science teaching as he holds a $\mathrm{PhD}$ in Science Education and he is well informed on history and philosophy issues. Because he is well informed on the "power" of science teachers' discourse and trained on these issues, in his lessons, he tries to communicate suitable views on NOS aspects.

Our proposal tries to turn into praxis the orientated towards discourse analysis suggesting that critical reflection on ways teachers and students construct making may enhance the range of possible actions (Lemke, 1995; Gee \& Green, 1998). Furthermore, Hanrahan (2002) argues that critical discourse analysis can be used to explore and negotiate the dominant discourse in teacher-student interactions in science classrooms.

Based on this argument, it is suggested the necessity to study science teachers' talk by teachers themselves in cooperation with researchers regarding aspects of NOS. Focusing on teachers' discursive repertoires and involving them in discourse analysis may encourage them to develop dexterity in determining appropriate approaches to communicate desired aspects of NOS within certain contexts (Gutierrez \& Rogoff, 2003).

4.1 Case Study: From "Will we communicate a bit?" to "To reach a solution of a problem ...there is not only one right way."

To investigate NOS views communicated by teachers' talk a case study was conducted. The study was part of a collaborative action research (Wells 2009) in which eight teacher-researchers participated. The researcher worked closely with the eight teacher-researchers to gradually establish and promote suitable collaborative inquiry conditions in their classroom by using the following principles and strategies (Piliouras \& Evaggelou 2012):

- Inquiry, as the organizing principle of curricular activities.

- Establishing a collaborative community.

- Using discursive strategies to scaffold students' learning.

- Activities designed to help students practice in using language:

- teaching students to talk science;

- bridging between colloquial and scientific language;

- teaching about science and scientific methods, and

- helping all students to use science in their own interest. 
- developing a metacognitive awareness of their own present thinking and the development of their thinking as they learn.

The actions of the collaborative action research were the following:

Action 1: Literature review concerning teacher-students' interactions

Action 2: Discourse analysis of teachers' talk during science lessons

Action 3: Exploration of possible alternatives of teacher communicative repertoires

Action 4: Examination of the emerging transformed discourse practices and their gradual modeling

Using discourse analysis tools that are derived mainly from the sociocultural educational tradition (Mortimer \& Scott, 2003), the researcher tried to involve actively the eight teacher-researchers in the analysis of their own discourse practices and transform them gradually into more collaborative inquiry ones (Piliouras, 2006).

Among the issues we studied and analyzed were teachers' communicative actions concerning NOS views. During the school years 2004-2005 and 2005-2006 we proceeded to the recording and the transcription of 32 teachings sequences of the teacher-researchers (4 recordings for every teacher) during science lessons and in teachers' talk discourse analysis concerning aspects of promoting collaborative inquiry conditions in their own classrooms.

Specifically, in relation to the NOS views communicated by the teachers, the researcher and participants of the study explored the discourses answering the following questions:

- Which image of science was presented (e.g. as a static or as a dynamic, changing and tentative one)?

- Which meanings were communicated regarding the methodology of science? (e.g. as a one and unique correct scientific method or not)?

- Which kinds of options discussed during lessons (i.e. historical, cultural and social influences on the practice and direction of science)?

- Which meanings were communicated about a series of scientific processes, (for example, measurement, observation, interpretation, conclusion, experiment, model and also elements concerning the distinction among processes, such as the difference between an observation and an interpretation)?

- Which meanings were communicated about the nature of language in general and the language of science in particular?

Next, a case study of two teaching sequences taught by a teacher-researcher who participated in the action research is discussed. In the beginning of the research, this teacher-researcher had two-years teaching experience. The first teaching sequence took place in the beginning of the collaborative action research with a $5^{\text {th }}$ grade class and the second at its end with a $6^{\text {th }}$ grade class. Throughout research the teacher-researcher in cooperation with the researcher and the other teacher researchers worked critically and reflectively analyzing his own talk during lessons. Among the aspects, he analyzed, were the examination of possible NOS views communicated by his talk in relation with our broader goal to promote a collaborative inquiry learning context.

4.1.1 Study and Analysis of a Teaching Sequence from the Initial Phase of the Research - "Will we communicate a bit?"

The science lesson studied and analyzed by the researcher and participants in the initial phase of the action research was entitled "Solids, liquids and gases". After examining teachers' communicative actions of this lesson undesirable teaching discourse strategies concerning a cooperative inquiry framework were identified. More specifically, the particular teacher-researcher appeared to discourage rather than encourage the expression of opinions from students or groups and monopolize the discussion by asking students to formulate specific responses. He also appeared to guide oppressively the learning process. Some desirable teaching strategies were identified as well. These were: individual student and group engagement in the learning process; introduction of the discourse of science by bridging it with students' discourse and student encouragement in order to expand their opinions and views.

The extract of a discussion taken place during the lesson-unit "Solids, liquids and gases" illustrates the findings of the analysis of these verbal accounts. Teacher and students discuss an experiment, included in student book. This involves three deferent in shape pots filled with liquid. Students are expected to arrive at the conclusion that the liquids take the shape of the pot. During the activity, the teacher, asked students to read from the student book and try to understand the procedure of the experiment, discussed with them and asked clarifications on what they need to do for its accomplishment. 
Extract 2: Initial Phase of the Research

1 (Teacher): Who will tell what this exercise asks you to do? What this exercise asks you to do? Read and tell me. What do you want?

2 (Students): Pots.

3 (Teacher): What does this exercise asks you to do? Read a bit the steps in the unit and ask what you need to do in this exercise. I ask you to answer me. Eponimakis (he speaks to the student's surname)

4 (Student 1): We empty...

5 (Teacher): (He interrupts) What does it ask you to do? Leave it we empty it. What does it ask you to do?

6 (Student 1): It asks you to...

7 (Teacher): Yes. Take water which is in the pot and to do with it what?

8 (Student 1): Here it is... and throw it.

9 (Teacher): Who can tell me? Come on!

10 (Student 2): And... throw it...

11 (Teacher): Be quite there, here here!

12 (Student 3): Shall we see the shape that water takes?

13 (Teacher): He asks her to take it (he shows the pot) and to do with it what? Take it. Tell it!

14 (Student 3): Eee...

15 (Teacher): And throw it...

16 (Student 3): Let's throw it into these three transparent pots.

17 (Teacher): Well, throw it. It is already in one, drop the other two and then notice what? ... Let me tell you ... [3s] Let me tell you, will we communicate a bit? Then, does it ask you to notice Georgia?

18 (Student 4): The shape that water takes in each pot.

Teacher's verbal actions seemed to create a static and one-dimensional meaning for the NOS. Students were strictly guided by the teacher who asked for specific answers and specific research methods. This repressive guidance, which required from students to say what the teacher wanted, indicated that there were specific answers and specific ways to interpret the process of inquiry activity. Representatives of reliable scientific knowledge were only the teacher and the school science book. The teacher appeared to guide almost absolutely the discussion as he required his students to say exactly what he wanted. He required his students to interpret what they had read, just as he interpreted those imposing an authoritative mode of language instead of an exploratory one in the initial phase of the lesson. At the same time he appeared to communicate a wrong view for the nature of interpretation of a text and its relation with observation. The teacher-researcher seemed to believe that students after reading the activity and observing the photo with the experimental apparatus would have understood the same thing that he understood himself. He appeared to create meanings with his speeches about the language exclusively as a system of transmitting information and not also as an exploratory system (Sutton, 1992). In this context students should be good "recipients" and should have understood immediately the teacher's verbal actions. Furthermore it is not only the teacher's communicative actions that seemed to discourage investigation but also his actions. When he received an unsatisfactory answer, he again appears to be directed other students seeking to hear the desirable answer (e.g. line 9, 13, 15). The teacher appeared to use the first person singular to indicate the view that the students' answers should be always filtered into the correctness by the teacher, the master of the class (e.g. line 1, 3).

Overall, in the initial phase of the collaborative action research teacher's interactive practices probably derived from a teacher-centered learning process with several features that were opposed to objectives set for the creation of collaborative inquiry learning conditions. His verbal accounts, in conjunction with his practices, often communicated not suitable views for all aspects of the learning process, for example the nature of teaching and learning and the nature of school science language. Although, in a theoretical level teacher adopted right views for our framework concerning NOS, in the real life settings, he appeared to achieve the exact opposite result due to his teaching and discourse practices. This surprised the teacher himself, who wonder how this could happen. This may be explained by the fact that the teacher had attended teacher-centered learning education throughout his life and so he was unable to act differently because he was not familiar with the appropriate collaborative repertoires and the relative NOS teaching discourse strategies and practices. It may also be the case that the teacher was not aware of the implications 
of his verbal accounts in the science learning process. That is to say, the teacher was not aware that such accounts may lead to particular undesirable meanings about NOS aspects despite his intentions.

4.1.2 Study and Analysis of a Teaching Sequence from Research's Final Phase - "... to reach a solution of the problem, there is no need to follow a way and there is not only one right way"

This teaching sequence was recorded and analyzed during the final phase of the research. Data analysis shows that the teacher in comparison with the previous phases of the project had appropriated discourse repertoires that led to the creation of more collaborative inquiry conditions and more appropriate NOS discourse pedagogical strategies. The lesson unit was about an open-ended problem that students were asked to solve collaboratively using springs, rubbers, strings, clips and other materials in any way and combination they wanted. The problem read as follows: "Which of the available items (a battery, a piece of plasticine) has the greatest weight?".

The extract (3) is a representative example of teacher-students' communicative interactions that took place during this lesson. In this extract students working in groups discuss possible solving methods, and propose specific solutions. Then, they are called by the teacher to present their methods to the class.

\section{Extract 3: Final Phase of the Research}

1 (Teacher): As soon as one, two, three, four teams have finished, please don't talk at all. ... So let's begin (he says the name of a child). We all hear what each group says.

2 (Student 1): (as a team representative) We will tie the spring with a string from its one end (at the same time, he shows what they will do with materials) and I will put the clip to its other end. On the other end of the string, we will put another clip and then we will connect the clip with the body that we want to measure.

3 (Teacher): Tell me simply! Tell children simply! What will you do? How? What are you going to observe in order to conclude which is heavier?

4 (Student 2): (helping the representative of his team) We will check the length of the spring.

5 (Teacher): Well, where will you put the objects? On the....? On the end of...?

6 (Student 1): The ... clip.

7 (Teacher): Good! There (pointing with his finger). Good! How will you measure the length of the spring you are talking about?

8 (Student 1): (the representative of the team speaks again) How ...how much more ... is the spring stretched ... in order to measure it with the ruler?

9 (Teacher): And in which case is heavier the body? Does this happen when the spring is stretched more or less?

10 (Student 1): More

11 (Teacher): Well, let's go to hear a completely different view from this team. Who will read the steps that you planned to do in order to solve this problem?

12 (Student 3): (as a representative of another team) We will make a scale. We will pa...

13 (Teacher): Could you speak a little louder?

14 (Student 3): (he speaks louder) We will pass the hole of the string in the ruler. Then, we will put plasticine on the one end of the ruler and the battery to the other end. Then, we lift the string with the ruler and we will see which body is heavier.

15 (Teacher): Can we see that a bit? Can we do it? It's a different idea. Hey? Let's see to what extent this idea is applied, shall we? (three students by the team is standing up - the teacher is directed to the group)

16 (Student 4): (from another group) Mr.! To do the same in our team?

17 (Teacher): You said you had another idea which you recorded. I will expect this idea from you ...

The extract 3 is characterized by many collaborative inquiry futures of the learning process. For instance, extensive contributions made by students and active participation and interaction as individual and as team members can be observed. Teacher-researcher appeared to use discursive strategies to scaffold students solving methods as well as inquiry as the organizing principle of this curricular activity.

Teacher's communicative accounts seemed to create non-static meanings about the NOS. The teacher appeared to urge students to find out to alternative solutions that might have application in real life (e.g. line 15). Thus, he 
seemed to create more suitable meanings about NOS, such as that there is no single method to do science, and that the proposed solutions should be articulated with arguments and evidence and be open to criticism and scrutiny (e.g. line 11).

The teacher appeared to guide groups appropriately and sounded more familiar with essential collaborative inquiry and interactive discourse skills than in the first teaching period (e.g. lines 1, 3, 11). Teacher and school book looked as if they were not the only valid sources of knowledge in this lesson. Students' views were elicitated, explored and used in the course of the lesson, and seemed to be equally important for the learning process (e.g. lines 7, 8). The participant teacher appeared to formulate questions to promote the exploration of positions, opinions and meanings presenting a more realistic image of scientific endeavor and the students' collaborative inquiry process.

The participant-teacher with his interactive contributions appears to pursue an exploratory approach to the problem, challenging the view of the unique correct scientific method (e.g. line 17). In addition, he seemed to seek to highlight the solutions that have been proposed by the groups as he asked for their evaluation like scientist do (e.g. line 15). The questions asked seemed to encourage the examination of views and solutions proposed by the groups. Also, the teacher-researcher did not appear to accept impetuous views expressed without seeking clarifications in comparison to the initial phase of research (e.g. line 7). He appears to encourage student contributions in the learning process, seek clarifications from them and. guide appropriately in order to ensure that there is a communication between all group members (e.g. line 3 )

Analysis of these accounts indicated that the teacher had adopted desirable characteristics of the framework set at beginning of the action research and promoted appropriate NOS pedagogical discourse strategies, such as: encouragement of cooperation and expression of opinions (e.g. lines 1 \& 11), ideas and solutions (e.g. lines 11 \& 12), development of inquiry skills (e.g. line 7), posing appropriate questions (e.g. line 15), seeking for explanations and arguments (e.g. line 3). It appeared that the teacher with such communicative repertoires promoted basic tenets of NOS like the notion that science is empirically based (e.g. line 7), and depends on human imagination and creativity.

The final phase of the research indicated a distinct shift in teaching practices as the participant-teacher used collaborative inquiry practices, gradually guided students more appropriately than in the forest phase, gave them time to work, interact and create their own solutions. Thus, he appeared to create a context for more appropriate NOS discourse strategies. A very interesting aspect of the above analysed teaching-learning sequence was that the teams constructed, combining materials in different ways, different types of dynamometers and scales. The table below shows both dialogues (abstract $4 \& 5$ ) and proposed solutions to the problem that gave two teams of the class.

Abstract 4 - concerns the $1^{\text {st }}$ category teams' solutions: dynamometer construction
Abstract 5 - concerns the $2^{\text {nd }}$ category teams' solutions: scale construction

(Student 1): We will tie the spring with a string from its one end (at (Teacher): Well, we will see other relevant the same time, he shows what they will do with materials) and I will experiments. Let this group sit down here put the clip to its other end. On the other end of the string, we will (students sit down at their desks). We will saw put another clip and then we will connect the clip with the body that a live performance from this team (he is we want to measure.

(Teacher): Tell me simply! Tell children simply! What will you do? addressed at the other teams). Well, Vasiliki is How? What are you going to observe in order to conclude which is heavier?

(Student 2): We will check the length of the spring.

(Vasiliki): We will put the string in the middle of the ruler.

(Teacher): Well, where will you put the objects? On the....? On the end of...?

(Student 1): The ... clip.

(Teacher): In the middle of the ruler (he is trying to make all student to watch on the

(Teacher): Good! There (pointing with his finger). Good! How will experimental procedure)...now. you measure the length of the spring you are talking about?

(Student 1): How ... how much more ... is the spring stretched ... in (Vasiliki): We will put the string in the middle order to measure it with the ruler? of the ruler. On the one end of the ruler, we will

(Teacher): And in which case is heavier the body? Does this happen when the spring is stretched more or less? place the battery and on the other end the plasticine, so $[\ldots]$ a scale.

(Student 1): More. 
To sum up, data analysis showed that the nature of teaching at the final phase of the program differentiates significantly from that of the initial phase. The teacher, carrying out the discourse analysis of his verbal accounts with the cooperation of the researchers, gradually communicated during science lessons more suitable NOS views. This probably has to do with a series of parameters, such as: the information the teacher received through the literature concerning teacher-students' interactions, and the gradual familiarization with collaborative inquiry strategies (action 1). However, the critical and reflective attitude adopted by the teacher probably enabled him reflect on his accounts. This led gradually to the transformation of the activities during the lessons and simultaneously in the transformation of his discourse practices and repertoires. As the participant- teacher noted: "By analysing my accounts, I discovered aspects of my teaching practices that I was not aware of them. I could not imagine the power of our talk."

\section{A Proposal of Discourse Analysis Oriented Actions for Promoting more Effective NOS Teaching}

Researches internationally emphasise the crucial role teachers can play in developing a basic NOS understanding on behalf of the students. What is also clear from recent research is that rarely do students receive instruction that contributes to better understandings of NOS unless their teachers have had some kind of professional development for teaching NOS (Akerson et al., 2009). Furthermore, research indicates the importance of training strategies that highlight explicitly aspects of the NOS and also the use of history and philosophy of science as an effective tool to stress the social and cultural character of the scientific knowledge.

Using discourse analysis and acting as teachers-researchers science teachers may reflect and transform their own view of NOS and teaching practices. It is very important teachers' engagement in reflective action and involvement in the analysis of their own verbal accounts. In our opinion teachers can't be familiarized with NOS pedagogical discourse strategies only with training. But they may be involved in the very practice and research by examining ways they teach and communicate during science lessons. The experience of this collaborative action research program, from which, in this article, a case study was presented, indicates that it is very important to involve teachers in research and provide them with descriptive tools to evaluate classroom activities and talk. The novelty of this effort was that participant teachers were involved in the discourse analysis procedure which gradually led in teachers' teaching awareness of views that were communicated on aspects concerning NOS in their classrooms during science lessons.

So, in this paper we argue for the value of discourse analysis of science teachers' talk as a reflective tool in order trace the meaning communicated on NOS during lessons. A possible series of actions within a framework of a collaborative action-oriented research analysis concerning teachers' talk could be the following:

Action 1: Be acquainted with NOS aspects and studying which contexts are appropriate for NOS teaching

Action 2: Examine the elements of NOS aspects communicated during science lessons.

Action 3: Be gradually acquainted with pedagogical knowledge to teach science as inquiry and appropriate discourse strategies to introduce explicitly NOS aspects.

Action 4: Enhance discourse practices concerning NOS teaching during lessons.

Action 5: Examine the emerging transformed discourse practices related with NOS teaching and its gradual modelling.

\section{References}

Abd-El-Khalick, F., \& Akerson, V. L. (2004). Learning as conceptual change: Factors mediating the development of preservice elementary teachers' views of the nature of science. Science Education, 88(5), 785-810. http://dx.doi.org/10.1002/sce.10143

Abd-El-Khalick, F., \& Lederman, N. (2000). Improving science teachers' conceptions of the nature of science: A critical review of the literature. International Journal of Science Education, 22(7), 665-702. http://dx.doi.org/10.1080/09500690050044044

Abd-El-Khalick, F., Bell, R.L., \& Lederman, N.G. (1998). The nature of science and instructional practice: Making $\begin{array}{lllll}\text { the } & \text { natural. } & \text { Science }\end{array}$ http://dx.doi.org/10.1002/(SICI)1098-237X(199807)82:4<417::AID-SCE1>3.0.CO;2-E

Adúriz-Bravo, A. (2003). Methodology and Politics: A Proposal to Teach the Structuring Ideas of the Philosophy of Science through the Pendulum. Science \& Education, 13(7), 717-731. 
Aikenhead, G.S. (2000). Renegotiating the culture of school science. In R. Millar, J. Leach, \& J. Osborne (Eds.), Improving science education: The contribution of research. Birmingham, UK: Open University Press, pp. 245-264.

Akerson, Cullen, Hanson. (2009). Fostering a community of practice through a professional development program to improve elementary teachers' views of nature of science and teaching practice. Journal of Research in Science Teaching, 46, 1090-1113. http://dx.doi.org/10.1002/tea.20303

Akerson, V.L., \& Abd-El-Khalick, F. (2000, April). The influence of conceptual change teaching in improving preservice teachers' conceptions of nature of science. Paper presented at the annual meeting of the National Association for Research in Science Teaching, New Orleans, LA.

Akerson, V.L., \& Abd-El-Khalick, F. S. (2005). "How should I know what scientists do - I am just a kid": Fourth grade students' conceptions of Nature of Science. Journal of Elementary Science Education, 17, 1-11. http://dx.doi.org/10.1007/BF03174669

Akerson, V.L., \& Volrich, M. L. (2006). Teaching nature of science explicitly in a first-grade internship setting. Journal of Research in Science Teaching, 43, 377-394. http://dx.doi.org/10.1002/tea.20132

Akerson, V.L., Abd-El-Khalick, F., \& Lederman, N.G. (2000). The Influence of a Reflective Activity Based Approach on Elementary Teachers' Conceptions of the Nature of Science. Journal of Research in Science Teaching, 295-317. http://dx.doi.org/10.1002/(SICI)1098-2736(200004)37:4<295::AID-TEA2>3.0.CO;2-2

Akerson, V.L., Buzzelli, C. A., \& Donnelly, L. A. (2010). On the nature of teaching nature of science: Preservice early childhood teachers' instruction in preschool and elementary settings. Journal of Research in Science Teaching, 47, 213-233.

American Association for the Advancement of Science-AAAS (1993). Benchmarks for Science Literacy. Oxford University Press.

Bell, R. L., Lederman, N. G., \& Abd-El-Khalick, F. (2000). Developing and acting upon one's conceptions of the nature of science: A follow-up study. Journal of Research in Science Teaching, 37, 563-581. http://dx.doi.org/10.1002/1098-2736(200008)37:6<563::AID-TEA4>3.0.CO;2-N

Burbules, N., \& Bruce, B. (2001). Theory and research on teaching as dialogue, In Richardson, V. (ed.), Handbook of research on teaching, pp. 1102 - 1121, American Educational Research Association.

Clough, M. P. (2006). Learners Responses to the Demands of Conceptual Change: Considerations for Effective Nature of Science Instruction. Science \& Education, 15(5), 463-494. http://dx.doi.org/10.1007/s11191-005-4846-7

Clough, M.P., \& Olson, J.K. (2004). The Nature of Science: Always part of the Science Story. The Science Teacher, 71(9), 28-31.

Driver, R., Leach, J., Millar, R., \& Scott, P. (1996). Young people's images of science. Open University Press.

Duschl, R.A. (1994). Research on The History and Philosophy of Science. In D. Gable (eds.), Handbook of research in science teaching, pp. 443-465, Macmillan, New York.

Gee, P. (1999). An Introduction to Discourse Analysis: Theory and Method. London, Routledge.

Gee, P., \& Green, J. (1998). Discourse Analysis, Learning, and Social Practice: A methodological study. Review of Research in Education, 23, 119-169. http://dx.doi.org/10.2307/1167289

Gutierrez, K., \& Rogoff, B. (2003). Cultural Ways of Learning: Individual Traits or Repertoires of Practice. Educational Researcher, 32(5), 19-25. http://dx.doi.org/10.3102/0013189X032005019

Hanrahan. (2002). Applying CDA to the Analysis of Productive Hybrid Discourses in Science Classrooms. Paper presented at the Annual Paper Conference of the Australian Association for Research in Education, Brisbane, Queensland, 1-5 December 2002.

Hicks, D. (1996). Contextual Inquiries: a Discourse-oriented Study of Classroom Learning, In D. Hicks (ed.), Discourse, Learning, and Schooling, Cambridge, pp. 104-141, Cambridge University Press. http://dx.doi.org/10.1017/cbo9780511720390.004

Hodson, D. (1988). Towards a philosophically more valid science curriculum. Science Education, 72(1), 19-40. http://dx.doi.org/10.1002/sce.3730720103 
Hodson, D. (1998). Teaching and learning science: Towards a personalized approach. Buckingham, UK: Open University Press.

Jenkins, E. (1996). The 'nature of science' as a curriculum component. Journal of Curriculum Studies, 28(2), 137-150. http://dx.doi.org/10.1080/0022027980280202

Johnston, A. T. (2001). A conceptual change analysis of nature of science conceptions: The deep roots and entangled vines of a conceptual ecology. Unpublished doctoral dissertation, University of Utah, Salt Lake City.

Lederman, N. G. (1992). Students' and teachers' conceptions about the nature of science: A review of the research. Journal of Research in Science Teaching, 29(4), 331-359. http://dx.doi.org/10.1002/tea.3660290404

Lederman, N. G. (1998). The state of science education: Subject matter without context. Electronic Journal of Science Education, 3(2), 1-7.

Lederman, N. G. (2007). Nature of science: Past, present, and future. In Abell, S., \& Lederman, N. (Eds.), Handbook of Research on Science Education, pp. 831-880, Lawrence Erlbaum Associates Publishers.

Lederman, N. G., Abd-El-Khalick, F., Bell, R. L., \& Schwartz, R. S. (2002). Views of Nature of Science questionnaire (VNOS): Toward valid and meaningful assessment of learners' conceptions of nature of science. Journal of Research in Science Teaching, 39(6), 497-521. http://dx.doi.org/10.1002/tea.10034

Lederman, N. G., Schwartz, R. S., Abd-El-Khalick, F., \& Bell, R. L. (1999, March). Preservice teachers and their nature of science instruction: Factors that facilitate success. Paper presented at the Annual Meeting of the National Association for Research in Science Teaching, Boston, MA.

Lederman, N.G. (1999). Teachers' understanding of the nature of science and classroom practice: Factors that facilitate or impede the relationship. Journal of Research in Science Teaching, 36(8), 916-29. http://dx.doi.org/10.1002/(SICI)1098-2736(199910)36:8<916::AID-TEA2>3.0.CO;2-A

Lederman, N.G., \& Lederman, J.S. (2004). Revising instruction to teach nature of science. The Science Teacher, 71(9), 36-39.

Lederman, N.G., Schwartz, R., Abd-El-Khalick, F., \& Bell, R.L. (2001). Preservice teachers' understanding and teaching of nature of science: An intervention study. Canadian Journal of Science, Mathematics, and Technology Education, 1, 135-160. http://dx.doi.org/10.1080/14926150109556458

Lemke, J.L. (1995). Textual Politics: Discourse and Social Dynamics. Bristol, PA: Taylor \& Francis.

Luke, A. (1995). Text and discourse in education: An introduction to critical discourse analysis. In Apple, M. (ed.), Review of research in education, 21, pp. 3-48, American Educational Research Association. http://dx.doi.org/10.2307/1167278

Matthews M.R., Gauld, C.F., \& Stinner, A. (2005). The pendulum: Its Place in science, culture and Pedagogy. In Matthews, M.R., Gauld, C.F., \& Stinner (eds.), The Pendulum: Scientific, Historical, Philosophical and Educational Perspectives, pp. 1-17, Springer. http://dx.doi.org/10.1007/1-4020-3526-8

Matthews, M. (1998). The nature of science and science teaching, In Fraser, B. J., \& Tobin, K. G. (Eds.), International Handbook of Science Education, pp. 981-999, Kluwer Academic Publishers. http://dx.doi.org/10.1007/978-94-011-4940-2_57

McComas, W. F. (2005). "Teaching the nature of science: What illustrations and examples exist in popular books on the subject?", e-proceedings of Eighth International History, Philosophy \& Science Teaching (IHPST) Conference, Leeds, UK (July 15-18), http://www.ihpst2005.leeds.ac.uk/

McComas, W.F., Clough, M.P., \& Almazroa, H. (1998). The role and character of the nature of science in science education. In McComas, W. F. (Ed.), The nature of science in science education. Rationales and strategies, pp. 3-39. Kluwer Academic Publishers.

Millar, R., \& Osborne, J. (eds.) (1998). Beyond 2000: Science education for the future. King's College: London.

Mortimer, E., \& Scott, P. (2003). Meaning Making in Secondary Science Classrooms. Maidenhead-Philadelphia: Open University Press.

National Research Council (2012). A Framework for K-12 Science Education: Practices, Crosscutting Concepts, and Core Ideas. Committee on a Conceptual Framework for New K-12 Science Education Standards. Board on Science Education, Division of Behavioral and Social Sciences and Education. Washington, DC: The National Academies Press. 
National Research Council-NRC (1996). National science education standards. National Academic Press.

Nott, M., \& Wellington, J. (1998). Eliciting, interpreting and developing teachers' understandings of the nature of science. Science \& Education, 7(6), 579-594. http://dx.doi.org/10.1023/A:1008631328479

Oliveira, A.W., Akerson, V.L., Colak, H., Pongsanon, K., \& Genel, A. (2012). The implicit communication of nature of science and epistemology during inquiry discussion. Science Education, 96, 652-684. http://dx.doi.org/10.1002/sce.21005

Osborne, J., Collins, S., Millar, R., \& Duschl, R. (2003). What "ideas-about-science" should be taught in school science? A Delphi study of the expert community. Journal of Research in Science Teaching, 40(7), 692-720. http://dx.doi.org/10.1002/tea.10105

Piliouras P., \& Evaggelou O. (2012). Teachers' inclusive strategies to accommodate 5th grade pupils' crossing of cultural borders in two Greek multicultural science classrooms. Research in Science Education, 42, 329-351. $\mathrm{http}: / / \mathrm{dx}$. doi.org/10.1007/s11165-010-9198-x

Piliouras, P. (2006). Collaborative inquiry during science lessons. An oriented to discourse analysis approach. Unpublished dissertation, Pedagogical department, University of Athens.

Roth, W.M., Goulart, M.I., \& Plakitsi, K. (2013a). Preparing Teachers for Early Childhood Science Teaching. In Roth, W.-M., Goulart, M.I.M., Plakitsi, K., Science Education during Preschool Years. A Cultural-Historical Approach. Dordrecht, The Netherlands: Springer, p. 161-180.

Roth, W.M., Goulart, M.I., \& Plakitsi, K. (2013b). Magnifying Effects with LIGHT. In Roth, W.-M., Goulart, M.I.M., Plakitsi, K., Science Education during Preschool Years. A Cultural-Historical Approach. Dordrecht, The Netherlands: Springer, p. 181-200.

Ryan, A.G., \& Aikenhead, G.S. (1992). Students' preconceptions about the epistemology of science. Science Education, 76, 559-580. http://dx.doi.org/10.1002/sce.3730760602

Ryder, J., \& Leach, J. (2008). Teaching about the epistemology of science in upper secondary schools: An analysis of teachers' classroom talk. Science \& Education, 17(2-3), 289-315. http://dx.doi.org/10.1007/s11191-006-9007-0

Schwartz, R.S., Lederman, N.G., \& Crawford B.A. (2004). Developing views of nature of science in an authentic context: An explicit approach to bridging the gap between nature of science and scientific inquiry. Science Education, 88(4), 610-645. http://dx.doi.org/10.1002/sce.10128

Seroglou, F., \& Adúriz-Bravo, A. (2007). Designing and evaluating nature-of-science activities for teacher education. Paper presented at the 9th International History, Philosophy and Science Teaching Conference, June 24-28, 2007, Calgary, Canada.

Sutton, C. (1992). Words, science and learning. Buckingham, United Kingdom: Open University Press.

Wells, G. (1999). Dialogic Inquiry. Toward a Sociocultural Practice and Theory in Education. Cambridge University Press. http://dx.doi.org/10.1017/cbo9780511605895

Wells, G. (2009). Dialogic inquiry as collaborative action research. In S. Noffke \& B. Somekh (Eds.), Handbook of Educational Action Research, pp. 39-48, London, Sage. http://dx.doi.org/10.4135/9780857021021.n6

Wertsch, J. (1991). Voices of the mind: A sociocultural approach to mediated action. Harvard University Press, Cambridge, MA.

Wertsch, J., \& Toma, C. (1995). Discourse and Learning in the Classroom: A Sociocultural Approach. In L. Steffe \& J. Gale (Eds.), Constructivism in Education, pp. 159-174, Mahwah, NJ: LEA. 